DOI: https://doi.org/10.24127/ajpm.v10i4.3470

\title{
PENGEMBANGAN BAHAN AJAR MATA KULIAH PROGRAM LINIER BERBANTUAN SOFTWARE LINDO
}

\author{
Feri haryati $^{{ }^{*}}$, Ellis Mardiana Panggabean ${ }^{2}$, Sri Wahyuni $^{3}$ \\ ${ }^{1 * 2.3}$ Universitas Muhammadiyah Sumatera Utara \\ *Corresponding author. \\ E-mail: $\quad$ feriharyati@umsu.ac.id ${ }^{\left.{ }^{*}\right)}$ \\ ellismardiana@umsu.ac.id ${ }^{21}$ \\ sriwahyuni@umsu.ac.id $^{3)}$
}

Received 08 January 2021; Received in revised form 27 February 2021; Accepted 28 December 2021

\begin{abstract}
Abstrak
Penelitian ini bertujuan untuk mengembangkan bahan ajar Program linier berbantuan software Lindo. Metode penelitian yang digunakan adalah penelitian pengembangan (developmental research) menggunakan tahapan perencanaan, perancangan, dan pengembangan yang diadopsi dari model pengembangan Thiagarajan dan mahasiswa semester $\mathrm{V}$ pendidikan matematika sebagai subyek penelitian. Instrumen yang digunakan terdiri dari lembar validasi yang diisi oleh ahli bidang pendidikan matematika, lembar penilaian kepraktisan mahasiswa, dan tes hasil belajar dengan soal pemecahan masalah. Kualitas modul yang dikembangkan ditinjau dari aspek kevalidan, aspek kepraktisan dan aspek keefektifan. Hasil uji kevalidan dari para ahli yang terdiri dari ahli materi, ahli media dan ahli bahasa diperoleh bahwa bahan ajar Program linier Berbantuan software Lindo termasuk pada kriteria kelayakan sangat valid. Uji kepraktisan oleh mahasiswa pengguna bahan ajar diperoleh bahwa bahan ajar program linier berbantuan software lindo termasuk dalam kriteria sangat praktis. Adapun uji efektivitas bahan ajar program linier berbantuan software lindo pada tes hasil belajar mahasiswa menggunakan soal kemampuan pemecahan masalah matematis mahasiswa menunjukkan bahwa kemampuan pemecahan masalah matematis kelas yang menggunakan bahan ajar program linier lebih baik daripada kelas konvensional . Berdasarkan ketiga hasil tersebut dapat disimpulkan bahwa bahan ajar program linier berbantuan software lindo memenuhi ketiga kriteria tersebut, yaitu: valid, praktis, dan efektif.
\end{abstract}

Kata kunci: Bahan ajar; pengembangan.

\begin{abstract}
This study aims to develop teaching materials for linear programming assisted by lindo software. The research method used is developmental research using the stages of planning, design, and development adopted from the Thiagarajan development model and fifth semester students of mathematics education as research subjects. The instrument used consisted of a validation sheet filled out by experts in the field of mathematics education, student practicality assessment sheets, and learning outcomes tests with problem solving questions. The quality of the developed modules is reviewed from the aspect of validity, practicality and effectiveness. The results of the validity test from experts consisting of material experts, media experts and linguists obtained that the Lindo software-assisted linear program teaching materials included in the eligibility criteria were very valid. The practicality test by students using teaching materials was found that the linear program teaching materials assisted by the Lindo software were included in the very practical criteria. The test of the effectiveness of linear programming teaching materials assisted by Lindo software on student learning outcomes tests using students' mathematical problem solving abilities showed that the mathematical problem solving abilities of classes using linear programming teaching materials were better than conventional classes. Based on these three results, it can be concluded that the linear programming teaching materials assisted by the Lindo software meet the three criteria, namely: valid, practical, and effective.
\end{abstract}

Keywords: Development; teaching materials.

This is an open access article under the Creative Commons Attribution 4.0 International License 
DOI: https://doi.org/10.24127/ajpm.v10i4.3470

\section{PENDAHULUAN}

Perkembangan teknologi saat ini sangat lah pesat. Dunia pendidikan pun mengalami dampak perkembangan tersebut. Salah satu teknologi yang dapat dimanfaatkan adalah teknologi komputer. Komputer dapat digunakan sebagai salah satu media pembelajaran yang efektif. Komputer saat ini telah didukung oleh berbagai macam software yang dapat kita gunakan untuk pembelajaran matematika, antara lain Lindo, SPPS untuk aplikasi statistik, Maple, Matlab, GeoGebra, Microsoft Mathematic, dan lain-lain.

Pelajaran matematika merupakan salah satu mata pelajaran yang memiliki manfaat besar dalam kehidupan. Matematika memberikan kesempatan kepada siswa untuk melatih mental mereka yang akan berpengaruh terhadap perkembangan intelektual mereka. Melalui pelajaran matematika siswa akan mampu belajar untuk memperoleh pengetahuan secara sistematis (Ayda \& Widjajanti, 2014).

Untuk mewujudkan pembelajaran matematika yang baik, terdapat beberapa permasalahan yang harus diselesaikan, Seperti permasalahan dalam proses kegiatan pembelajaran. Penggunaan metode yang kurang bervariasi, kurangnya penggunaan media pembelajaran serta pembelajaran yang selalu menekankan kepada hasil belajar peserta didik tanpa memperhatikan proses pembelajaran yang bisa menyebabkan proses pembelajaran matematika terkesan monoton dan kurang kreatif (Yulianti, Zulkardi, \& Siroj, 2013).

Menurut Peraturan Pemerintah Nomor 32 Tahun 2013 tentang Standar Nasional Pendidikan menyatakan bahwa pendidik harus memiliki kualifikasi akademik dan kompetensi sebagai agen pembelajaran, sehat jasmani dan rohani, serta memiliki kemampuan untuk mewujudkan tujuan pendidikan nasional. Selain itu committee on undergraduate program in mathematics (CUPM) menyatakan bahwa setiap mata kuliah dalam matematika hendaknya dapat membantu mahasiswa dalam pengembangkan kemampuan analisis, penalaran kritis, pemecahan masalah dan keterampilan komunikasi. Namun hal itu berbeda dengan fakta yang diungkapkan oleh ( As'ari, Mahmudi, \& Nuerlaelah, 2018) yaitu sebagian besar mahasiswa (calon guru) berada pada level berpikir kritis rendah.

Berdasarkan hasil pra penelitian (Mei 2019), dari 80 mahasiswa menunjukkan kurangnya ketertarikan pada mata kuliah program linier. Mahasiswa kurang aktif pada saat pembelajaran di kelas. Hal ini terlihat pada rendahnya hasil tugas harian mahasiswa pada saat mengerjakan soal program linier yang berkaitan dengan kehidupan sehari hari. Tugas diberikan bertujuan untuk meningkatkan kemampuan pemecahan masalah matematis mahasiswa. Namun mahasiswa kesulitan menyelesaikan soal tersebut.

Keterangan tersebut menambah keyakinan bahwa sudah sepatutnya dilakukan pencarian akar masalah kenapa sebagian besar mahasiswa memiliki level berpikir kritis yang rendah dan kurang tertarik pada mata kuliah program linier. Penelusuran lebih dalam dilakukan dengan melakukan wawancara kepada mahasiswa dan memperoleh hasil bahwa algoritma penyelesaian soal pada program linier terlalu panjang. Sehingga perlu ada upaya memperbaiki konten materi yang harus disampaikan kepada mahasiswa dalam bentuk perbaikan bahan ajar. 
DOI: https://doi.org/10.24127/ajpm.v10i4.3470

\begin{abstract}
Ketepatan bahan ajar yang disusun akan membantu proses penalaran siswa untuk memahami konsep dasar, mengembangkan pengertian siswa, memberi motivasi siswa untuk mengembangkan pemikirannya, serta menumbuhkan kreativitas berpikir yang menggunakan prosedure matematis ( purnomo, 2011).
\end{abstract}

Penggunaan bahan ajar berbantuan software lindo dapat meningkatkan hasil belajar mahasiswa (Zulmaulida, 2013). Penggunaan software lindo dapat menyelesaikan permasalahan program linier dengan mudah, cepat dan akurat bahkan bahkan mampu menyelesaikan masalah program linier sampai 100 fungsi kendala dan dapat meningkatkan hasil belajar mahasiswa (Arifin, 2018).

Beberapa penelitian terdahulu telah banyak yang mengkaji tentang pengembangan bahan ajar dan pengguna software Lindo dalam pembelajaran program linier untuk meningkatkan hasil belajar mahasiswa . Namun dari semua penelitian yang telah dilakukan terkait pengembangan bahan ajar tersebut belum ada pengembangan bahan ajar yang fokus untuk mengembangkan kemampuan pemecahan masalah matematis mahasiswa.

Dari uraian masalah dan pendapat-pendapat yang telah diungkapkan di atas, maka perlunya bahan ajar mata kuliah program linier berbantuan software Lindo, yang merupakan bahan ajar yang mengikuti perkembangan ilmu pengetahuan dan teknologi.

\section{METODE PENELITIAN}

Metode penelitian yang digunakan adalah penelitian pengembangan (developmental research) dengan subyek penelitian sebanyak 40 mahasiswa semester $\mathrm{V}$ program study pendidikan matematika Universitas Muhammadiyah Sumatera Utara. Penelitian dan pengembangan difokuskan pada pengembangan bahan ajar Program Linier. Pengembangan bahan ajar menggunakan 4D (Thiagarajan, 1974) yang terdirii dari 4 tahapan yaitu:

\section{Define}

Pada tahap ini dilakukan kegiatan analisis kebutuhan pengembangan, syarat-syarat pengembangan produk yang sesuai dengan kebutuhan pengguna serta model penelitian dan pengembangan (model $\mathrm{R} \& \mathrm{D}$ ) yang cocok digunakan untuk mengembangkan produk. Analisis bias dilakukan melalui studi literatur atau penelitian pendahuluan.

\section{Design,}

tahap design terdiri empat tahapan kegiatan yaitu : Menyusun tes kriteria memilih media pembelajaran yang sesuai dengan materi dan karakteristik peserta didik.

\section{Develop}

Pada tahap ini dilakukan dua kegiatan yaitu: expert appraisal dan developmental testing. Expert appraisal merupakan teknik untuk memvalidasi rancangan produk. Dalam kegiatan ini dilakukan evaluasi oleh ahli dalam bidangnya. Tujuan evaluasi untuk memperbaiki materi dan rancangan pembelajaran yang telah disusun. Developmental testing merupakan kegiatan uji coba rancangan produk pada sasaran subjek yang sesungguhnya. Pada saat uji coba ini dicari data respon, reaksi dan komentar.

\section{Disseminate.}

Kegiatan terakhir dari tahap ini adalah melakukan packaging 
(pengemasan), diffusion dan adoption. Tahap ini dilakukan supaya produk dapat dimanfaatkan oleh orang lain. Pengemasan model pembelajaran dapat dilakukan dengan mencetak buku panduan penerapan model pembelajaran. Setelah buku dicetak, buku tersebut disebarluaskan supaya dapat diserap (difusi) atau dipahami orang lain dan digunakan (diadopsi) pada kelas mereka. Pada tahapan ini tidak dilaksanakan dikarena kondisi covid 19.

Pengembangan bahan ajar menggunakan kriteria valid dan praktis. Data kevalidan diperoleh menggunakan angket validasi oleh ahli sebanyak 6 orang dosen yang terdiri dua orang ahli materi, dua ahli media yang berasal dari dosen Matematika dan dua ahli bahasa dari dosen bahasa Indonesia. Data kepraktisan diperoleh dari hasil angket respon mahasiswa. Data angket validasi dan kepraktisan dalam penelitian ini merupakan data deskriptif persentase.

Dalam analisis deskriptif persentase, perhitungan yang digunakan untuk mengetahui kriteria valid dan praktis bahan ajar berdasarkan persentase skor dari angket. Kriteria skor penilaian validasi analisis nilai rata-rata yang digunakan seperti tercantum pada Tabel 1. Selanjutnya data hasil perolehan skor diubah dalam bentuk persentase dengan menggunakan rumus 1 .

$$
\mathrm{P}=\frac{\sum x}{\sum x_{i}} \times 100 \%
$$

Untuk melihat efektifitas produk menggunakan data pretest-postest yang mengunakan instrument tes tertulis dalam bentuk Essay. Tes disusun berdasarkan indikator kemampuan pemecahan masalah matematis. Hasil tes ini diukur dengan menggunakan normalitas gain (N-gain) kemudian dianalisis dengan uji paired sample ttest berbantu software SPSS.

Tabel 1. Kriteria uji validasi dan uji kepraktisan

\begin{tabular}{ccll}
\hline \multirow{2}{*}{ No } & \multirow{2}{*}{ Persentase } & \multicolumn{2}{c}{ Kriteria } \\
\cline { 3 - 4 } & & Valid & Praktis \\
\hline 1 & $80 \% \leq x<100 \%$ & $\begin{array}{l}\text { Sangat } \\
\text { valid }\end{array}$ & $\begin{array}{l}\text { Sangat } \\
\text { praktis }\end{array}$ \\
2 & $60 \% \leq x<80 \%$ & valid & Praktis \\
3 & $40 \% \leq x<60 \%$ & cukup & cukup \\
& & valid & praktis \\
4 & \multirow{2}{*}{$20 \% \leq x<40 \%$} & Kurang & Kurang \\
& & valid & praktis \\
5 & $0 \% \leq x<20 \%$ & $\begin{array}{l}\text { Sangat } \\
\text { kurang }\end{array}$ & $\begin{array}{l}\text { Sangat } \\
\text { kurang } \\
\end{array}$ \\
& & valid & praktis \\
\hline
\end{tabular}

\section{HASIL DAN PEMBAHASAN}

Pengembangan modul diawali dengan tahap pendefinisian, perancangan dan pengembangan. Berikut gambaran hasil penelitian yang telah dilakukan dari tahap pendefinisian, perancangan, dan pengembangan.

\section{Tahap Pendefinisian}

Pada tahap pendefinisian diawali dengan observasi awal tugas mahasiswa, nilai akhir mahasiswa serta keefektifan mahasiswa pada saat pembelajaran. Selain itu observasi juga dilakukan melalui wawancara kepada mahasiswa tentang kesulitan untuk memahami materi program linier. Langkah selanjutnya adalah perumusan capaian mata kuliah. Adapun capaian mata kuliah tersebut adalah:

1. Mahasiswa mampu menguasai teori, konsep, prinsip, prosedural keilmuan melalui bukti induktif dan deduktif serta aksiomatis dalam bidang kajian Pemograman Linear.

2. Mahasiswa mampu memahami konsep, prinsip, struktur, pola pikir keilmuan yang mendukung Pemograman Linear dalam bentuk dan konsep matematika di dalam memecahkan masalah. 
3. Mahasiswa mampu menerapkan dalam kehidupan sehari hari dari apa yang diperoleh dikelas

4. Mahasiswa mampu mengaplikasikan penyelesaian program linier dengan menggunakan software Lindo

5. Mahasiswa mampu memodelkan permasalahan kedalam pemodelan matematik dan dapat mengaplikasinkan menggunakan software Lindo

6. Mahasiswa mampu menkreasikan dan membuat soal soal yang berkaitan dengan kehidupan sehari hari

\section{Tahap Perancangan}

Langkah selanjutnya memulai untuk membuat desain awal bahan ajar Program Linier berbantuan Lindo. Dari hasil analisis materi dan tujuan pembelajaran maka untuk desain awal bahan ajar Program Linier yang dihasilkan dalam penelitian ini membahas satu topik/bab yaitu : 1) Program linier; 2) Pertidaksamaan linier; 3) Kombinasi linier; 4) Metode simplek; 5) Dualitas; 6) Transportasi; dan 7) Penugasan.

Selain itu contoh sampul dan bagian dari isi yang dirancang dapat dilihat pada Gambar 1.

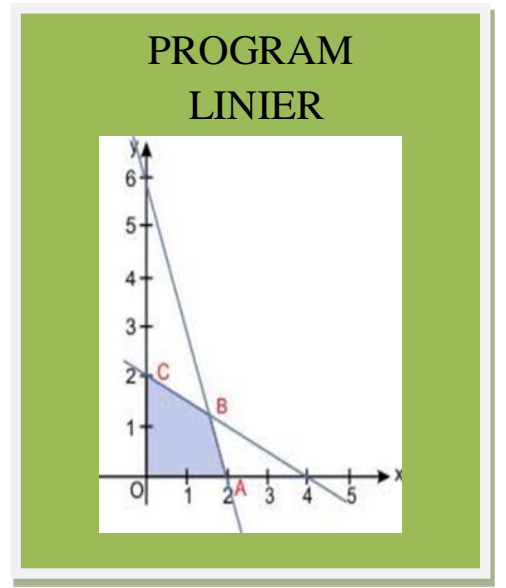

Gambar 1.Sampul bahan ajar
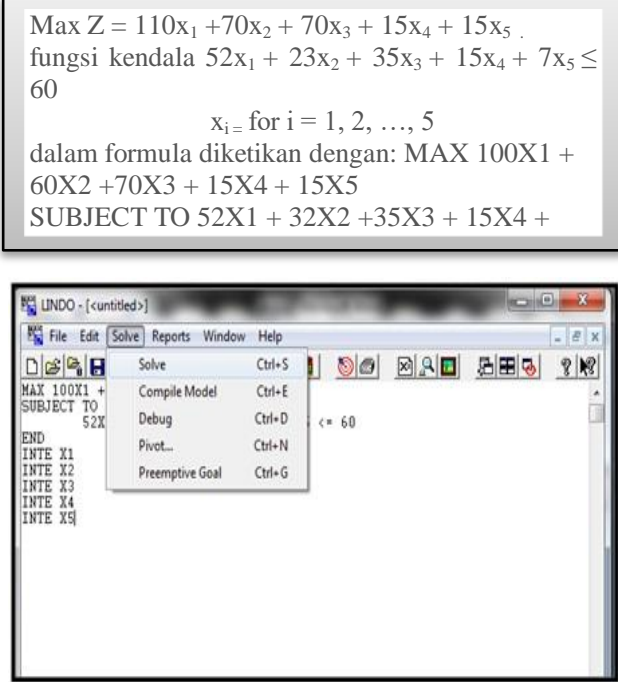

Gambar 2. Isi bahan ajar

\section{Tahap Pengembangan}

Setelah dilakukan perancangan awal bahan ajar program linier selanjutnya dilakukan validasi oleh para ahli yang terdiri dari ahli media, ahli materi dan ahli bahasa untuk menilai kevalidan dari bahan ajar Program Linier sebelum diujicobakan kepada mahasiswa. Adapun Validasi ahli terdiri dari beberapa orang dosen Matematika dan Bahasa Indonesia. Rekapitulasi hasil penilaian dari ahli materi, ahli media dan ahli bahasa secara keseluruhan disajikan dalam tabel 2

Tabel. 2 Rekapitulasi hasil uji validasi

\begin{tabular}{|c|c|c|c|c|}
\hline No & Validator & - Skor & Persentase & $\begin{array}{c}\text { Kriteria } \\
\text { Kelayakan }\end{array}$ \\
\hline 1 & $\begin{array}{c}\text { Ahli } \\
\text { Media }\end{array}$ & 45,5625 & $81 \%$ & $\begin{array}{l}\text { Sangat } \\
\text { Valid }\end{array}$ \\
\hline 2 & $\begin{array}{c}\text { Ahli } \\
\text { Materi }\end{array}$ & 46,125 & $82 \%$ & $\begin{array}{c}\text { Sangat } \\
\text { Valid }\end{array}$ \\
\hline 3 & $\begin{array}{c}\text { Ahli } \\
\text { Bahasa }\end{array}$ & 47,25 & $84 \%$ & $\begin{array}{c}\text { Sangat } \\
\text { Valid }\end{array}$ \\
\hline
\end{tabular}

Berdasarkan Tabel 2 hasil penilaian dari keseluruhan para ahli baik itu ahli materi, media dan bahasa menunjukan bahwa bahan ajar program linier sangat valid sehingga desain bahan ajar program linier yang dikembangkan oleh layak digunakan 
atau diujicoba tanpa revisi. Tetapi para Ahli juga memberikan beberapa masukan dan komentar

Komentar dari Ahli menyampaikan bahwa perlunya penambahan soal untuk tiap $\mathrm{BAB}$, selain itu saran para ahli dibuat ingkasan. Sedangkan komentar dari ahli media, tampilan cover dan isi dibuat semenarik mungkin. Untuk Ahli isi menyampaikan bahwa bahasa yang digunakan sudah baik .

Setelah diperoleh hasil validitas dari para ahli, bahan ajar program linier diujicobakan kepada mahasiswa.. Uji coba selanjutnya adalah uji coba kepada subjek penelitian yaitu mahasiswa yang dilakukan untuk mengukur kepraktisan dari bahan ajar program linier yang dikembangkan. Uji coba kepraktisan dilihat berdasarkan tiga aspek yaitu dari sisi tampilan bahan ajar, penyampaian materi ajar dan manfaat yang diperoleh mahasiswa dari pembelajaran. Adapun hasil dari uji coba kepraktisan produk ditunjukkan oleh persentase rata-rata hasil penilaian mahasiswa dapat dilihat pada pada Tabel 3 .

Tabel.3 Uji coba kepraktisan produk

\begin{tabular}{clcc}
\hline No & $\begin{array}{l}\text { Indikator } \\
\text { Penilaian }\end{array}$ & Persentase & $\begin{array}{c}\text { Kriteria } \\
\text { Kelayakan }\end{array}$ \\
\hline 1 & $\begin{array}{l}\text { Tampilan Bahan } \\
\text { Ajar }\end{array}$ & $81 \%$ & $\begin{array}{c}\text { Sangat } \\
\text { Valid } \\
2\end{array}$ \\
$\begin{array}{l}\text { Penyajian } \\
\text { Materi }\end{array}$ & $82 \%$ & $\begin{array}{c}\text { Sangat } \\
\text { Valid }\end{array}$ \\
3 & $\begin{array}{l}\text { Manfaat } \\
\text { pembelajaran }\end{array}$ & $84 \%$ & $\begin{array}{c}\text { Sangat } \\
\text { Valid }\end{array}$ \\
\hline
\end{tabular}

Uji coba selanjutnya yaitu untuk mengukur keefektifan bahan ajar yang digunakan dengan melihat hasil pretestpostest kelas eksperimen dan kontrol. Pada kelas eksperimen menggunakan bahan ajar berbantuan software Lindo sedangkan kelas kontrol tidak menggunakan bahan ajar software lindo Adapun Rekapitulasi hasil pengukuran $\mathrm{N}$-gain disajikan dalam Tabel 4
Tabel. 4 N-Gain

\begin{tabular}{lcc}
\hline Kelas & Mean & $\begin{array}{c}\text { Standar } \\
\text { Deviasi }\end{array}$ \\
\hline Eksperimen & 0,3183 & 0,058 \\
Kontrol & 0,1379 & 0,0627 \\
\hline
\end{tabular}

Secara ringkas skor N-Gain kemampuan pemecahan masalah matematis mahasiswa disajikan dalam Gambar 3. Berdasarkan Tabel 4 terdapat beberapa kesimpulan yang berkaitan dengan kemampuan pemecahan masalah matematis yang dapat diungkap, yaitu: rerata skor $N$-Gain kemampuan pemecahan masalah matematis mahasiswa kelompok eksperimen tergolong ke dalam kategori sedang, sedangkan rerata skor $\mathrm{N}$-Gain pemecahan masalah matematis mahasiswa kelompok kontrol tergolong ke dalam kategori rendah. Selain itu standard deviasi kelas eksperimen lebih kecil daripada kelas kontrol. Hal ini menunjukkan bahwa pembelajaran dengan bahan ajar berbantuan software lindo lebih menyebar daripada pembelajaran tanpa menggunakan bahan ajar software Lindo

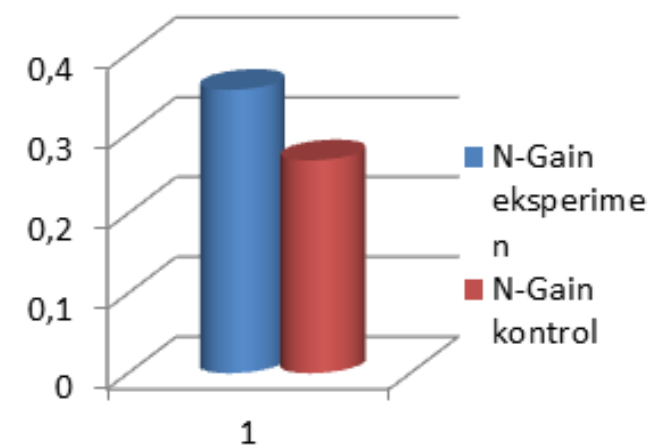

Gambar 3. Diagram N-Gain

Untuk mengetahui kebenaran rerata di atas perlu dilakukan perhitungan pengujian statistik dengan menggunakan uji perbedaan rerata dua populasi terhadap hipotesis berikut. 
DOI: https://doi.org/10.24127/ajpm.v10i4.3470

\section{Hipotesis 1:}

"Peningkatan kemampuan pemecahan masalah matematis mahasiswa yang menggunakan bahan ajar berbantuan software lindo lebih baik daripada mahasiswa yang memperoleh pembelajaran tanpa menggunakan bahan ajar software lindo".

Sebelum melakukan uji perbedaan rerata, terlebih dahulu dilakukan uji normalitas dan uji homogenitas terhadap skor $N$-Gain. Skor tersebut diperoleh dari $\mathrm{N}$-Gain kemampuan pemecahan masalah matematis mahasiswa kelompok eksperimen dan data $\mathrm{N}$-Gain kemampuan pemecahan masalah matematis mahasiswa kelompok kontrol.

Untuk melihat apakah data berasal dari populasi yang berdistribusi normal, dilakukan uji normalitas. Hipotesis uji normalitas skor $N$-Gain kemampuan pemecahan masalah matematis kelompok eksperimen dan kelompok kontrol adalah:

$\mathrm{H}_{0}$ : Sampel berasal dari populasi yang berdistribusi normal

$\mathrm{H}_{1}$ : Sampel berasal dari populasi yang tidak berdistribusi normal

Uji statistik yang digunakan adalah Shapiro-Wilk pada kedua kelompok data. Dengan kriteria uji, pada taraf signifikansi $\alpha$ tolak $\mathrm{H}_{0}$ jika $p$ value lebih kecil dari $\alpha$. Rangkuman hasilnya dapat dilihat pada Tabel 5.

Tabel 5. Uji Normalitas $N$-Gain

\begin{tabular}{lccc}
\hline \multirow{2}{*}{ Kelas } & \multicolumn{3}{c}{ Shapiro-Wilk } \\
\cline { 2 - 4 } & Statistic & Df & Sig. \\
\hline Eksperimen & .970 & 33 & .469 \\
Kontrol & .949 & 33 & .123 \\
\hline
\end{tabular}

Dari Tabel 5. diperoleh nilai signifikansi (sig.) masing-masing sebesar 0,469 dan 0,123 untuk peningkatan (N-Gain) kemampuan pemecahan masalah matematis mahasiswa pada kelompok eksperimen dan kelompok kontrol. Pada taraf signifikansi $\alpha=0,05$, nilai signifikansi tersebut lebih besar dari nilai $\alpha=0,05$ sehingga hipotesis nol diterima. Artinya, kedua kelompok data skor gain peningkatan kemampuan pemecahan masalah matematis mahasiswa ini berdistribusi normal.

Karena data rerata peningkatan (N-Gain) kemampuan pemecahan masalah matematis mahasiswa di kedua kelas tersebut berdistribusi normal, maka perlu dilakukan uji homogenitas. Perhitungan uji homogenitas N-Gain dapat dilihat pada Tabel 6 .

Tabel 6. Uji homogenitas n-gain

\begin{tabular}{llll}
\hline Levene Statistic & df1 & df2 & Sig. \\
\hline 1.171 & 7 & 19 & .364 \\
\hline
\end{tabular}

Berdasarkan tabel 6 diketahui bahwa nilai signifikansi hitung lebih besar dibandingkan nilai $\alpha=0,05$, sehingga $\mathrm{H}_{0}$ diterima, artinya varians pada kelas eksperimen dan kontrol adalah sama. Karena data berdistribusi normal dan variansnya homogen maka selanjut dilakukan untuk perbedaan peningkatan (N-Gain) kemampuan pemecahan masalah matematis mahasiswa di kelas eksperimen dan kontrol menggunakan uji Independendent sample T Test.

Untuk mengetahui kebenaran rerata di atas perlu dilakukan perhitungan pengujian statistik dengan menggunakan uji perbedaan rerata dua populasi terhadap hipotesis berikut. Untuk mengetahui signifikansi perbedaan rerata kedua kelompok digunakan rumusan hipotesis uji perbedaan rerata peningkatan (N-Gain) kemampuan pemecahan masalah matematis dengan hipotesis sebagai berikut: 
DOI: https://doi.org/10.24127/ajpm.v10i4.3470

$\mathrm{H}_{0}$ : Peningkatan kemampuan pemecahan masalah matematis mahasiswa yang menggunakan bahan ajar berbantuan Sofware Lindo sama dengan peningkatan kemampuan pemecahan masalah matematis mahasiswa yang memperoleh pembelajaran tanpa menggunakan bahan ajar Software Lindo.

$\mathrm{H}_{1}$ : Peningkatan kemampuan pemecahan masalah matematis mahasiswa yang menggunakan bahan ajar berbantuan Sofware Lindo sama lebih baik daripada mahasiswa yang memperoleh pembelajaran tanpa menggunakan bahan ajar Software Lindo.

Uji statistik menggunakan SPSS pada kedua kelompok data. Dengan kriteria uji, pada taraf signifikansi $\alpha$ tolak $\mathrm{H}_{0}$ jika $p$-value lebih kecil dari $\alpha$. hasil rangkumannya dapat dilihat pada Tabel 7.

Tabel.7 Uji perbedaan rataan $n$-gain

\begin{tabular}{crrr}
\hline $\mathbf{T}$ & \multicolumn{1}{c}{ Df } & Sig. (2-tailed) & $\begin{array}{c}\text { Std. Error } \\
\text { Difference }\end{array}$ \\
\hline 5.365 & 64 & .000 & .0149856 \\
5.365 & 63.762 & .000 & .0149856 \\
\hline
\end{tabular}

Dari Tabel diketahui bahwa nilai signifikansi (sig.) sebesar 0,000 lebih kecil dari nilai $\alpha=0,05$, sehingga dapat disimpulkan bahwa hipotesis nol ditolak. Artinya, skor peningkatan kemampuan pemecahan masalah matematis mahasiswa yang memperoleh pembelajaran menggunakan bahan ajar berbantuan Sofware Lindo lebih baik daripada mahasiswa yang memperoleh pembelajaran menggunakan bahan ajar Software Lindo.

Berdasarkan hasil penelitian menunjukkan bahwa hasil uji kevalidan dari para ahli yang terdiri dari ahli materi, ahli media dan ahli bahasa diperoleh bahwa bahan ajar Program linier Berbantuan software Lindo termasuk pada kriteria kelayakan sangat valid. Uji kepraktisan oleh mahasiswa pengguna bahan ajar diperoleh bahwa bahan ajar program linier berbantuan software lindo termasuk dalam kriteria sangat praktis.

Adapun uji efektivitas bahan ajar program linier berbantuan software lindo pada tes hasil belajar mahasiswa menggunakan soal kemampuan pemecahan masalah matematis mahasiswa menunjukkan bahwa kemampuan pemecahan masalah matematis kelas yang menggunakan bahan ajar program linier lebih baik daripada kelas konvensional, maka dari ketiga hasil tersebut dapat disimpulkan bahwa bahan ajar program linier berbantuan software lindo memenuhi ketiga kriteria tersebut, yaitu: valid, praktis, dan efektif. Jadi bahan ajar tersebut dapat meningkatkan kemampuan pemecahan masalah matematis mahasiswa pada mata kuliah program linier, karena soal yang diberikan saat uji keefektivan menggunakan soal kemampuan pemecahan masalah matematis mahasiswa.

Hasil ini sejalan dengan penelitian yang dilakukan oleh (Zulmaulida \& Saputra, 2014) yang menunjukkan bahwa penggunaan Software Lindo sebagai media pembelajaran dapat meningkatkan hasil belajar mahasiswa pada mata kuliah program linier. Sejalan juga dengan penelitian (Arifin, 2018) yang menunjukkan bahwa Software Lindo ini dapat menyelesaikan permasalahan program linear dengan muda, cepat dan akurat bahkan mampu menyelesaikan masalah program linear sampai 100 constraints (fungsi kendala). Keefektifan penggunaan bahan ajar Program Linier 
dapat meningkatkan aktivitas belajar. Mahasiswa termotivasi mengikuti pembelajaran, lebih mandiri belajarnya serta untuk berdiskusi.

\section{KESIMPULAN DAN SARAN}

Bahan ajar Program Linier Berbantuan Software Lindo yang dikembangkan memenuhi 3 indikator, yaitu: valid, praktis, dan efektif. Penggunaan bahan ajar dalam pembelajaran untuk meningkatkan kemampuan pemecahan masalah matematis dan memunculkan ketertarikan mahasiswa terhadap mata kuliah program linier.

Uji keefektivan pada penelitian ini berbeda dengan penelitian sebelumnya. Pada penelitian ini uji keefektivan menggunakan hasil postes dari soal kemampuan pemecahan masalah matematis mahasiswa. Sedang pada penelitian sebelumnya keefektifan diukur hanya soal hasil belajar mahasiswa. Hal ini dikarena soal yang disediakan pada bahan ajar program linier berbantuan software Lindo menggunakan soal yang mengandung indikator untuk meningkatkan kemampuan pemecahan masalah matematis mahasiswa.

Harapan kedepannya bahan ajar ini dapat digunakan untuk mengukur kemampuan matematis lainnya seperti kemampuan komunikasi, kemampuan penalaran dan kemampuan matematis lainnya dan bahan ajar ini bisa digunakan pada pembelajaran di kelas untuk mengukur hasil belajar mahasiswa maupun siswa SMA dengan berbagai level kemampuan, baik rendah , sedang maupun tinggi.

\section{DAFTAR PUSTAKA}

Arifin, Z. (2018). Penggunaan Software Lindo dalam Matakuliah Program Linear. Jurnal Theorems, 3(1), 119.
Astutik, E. P., \& Fitriatien, S. R. (2018). Integrating MATLAB in teaching linear programming at the university level. International Journal on Teaching and Learning Mathematics, 1(2), 8489.

As'ari, A. R., Mahmudi, A., \& Nuerlaelah, E. (2018). Our Prospective Mathematic Teachers Are Not. Journal on Mathematics Education, 8(2), 145-156.

Hardiyantari,O. (2017). Pengembangan multimedia pembelajaran interaktif menggunakan teknik dinamis pada mata pelajaran produktif teknik komputer dan jaringan untuk siswa SMK kelas X. Jurnal Inovasi Teknologi Pendidikan, 4(1), 77-83.

Kania, N. (2017). Efektivitas Alat Peraga Konkret Terhadap Visual Thinking Siswa. Jurnal THEOREMS (The Original Research of Mathematics), 1(2), 64-71.

Nugroho, P. B., Badawi, \& Prihatmojo, A. (2021). Pengembangan Bahan Ajar Berbentuk Video Pembelajaran Berbasis Data Covid -19 Untuk Meningkatkan Kewaspadaan Mahasiswa Terhadap Hoaks. AKSIOMA, 10(2), 467-478

Novalia, H., \& Noer, S. H. (2019). Pengembangan Modul Pembelajaran Matematika dengan Strategi PQ4R untuk Meningkatkan Kemampuan Berpikir Kreatif dan Kemandirian Belajar Siswa SMA. Jurnal Penelitian Dan Pembelajaran Matematika, 12(1), 51-65

Octaria, D. (2016). KEMAMPUAN PEMECAHAN MASALAH MATEMATIS MELALUI PROBLEM BASED. Prosiding 
DOI: https://doi.org/10.24127/ajpm.v10i4.3470

Seminar Nasional Pendidikan. 1, pp. 402-413. Palembang: Fakultas Keguruan dan Ilmu Pendidikan.

Purnomo, D. (2011). Pengembangan Bahan Ajar Matematika Sebagai Sarana Pengembangan Kreativitas Berpikir. jurnal aksioma, 1(2), 18.

Rosiyanti, H. (2016). Penggunaan Software Lindo Dengan Metode Pembelajaran Penemuan Terbimbing Untuk Meningkatkan Motivasi Belajar Mahasiswa Matematika Angkatan 2013 Pada Mata Kuliah Program Linier. Jurnal Fibonaci, 2(2), 1-9

Sutikno, M. S. (2013). Belajar dan Pembelajaran (1 ed.). Surakarta: Lombok Holistica.

Sugiyono. (2014). Metode Penelitian Kuantitatif Kualitatif dan $R \& D$. YOgyakarta: Alfabeta.

Ibrahim, N. (2013). PRINSIP-PRINSIP DESAIN PEMBELAJARAN. Mataram: JAKARTA PRENADA MEDIA GROUP .

Susanto, F., \& Ayuni Suri, I. R. (2017). Pengembangan Perangkat Pembelajaran Model Kooperatif Tipe NHT Dengan Strategi Pemecahan Masalah Matematis Bagi Peserta Didik SMP Di Kavbupaten Pringsewu . Jurnal Aksioma, 6(3), 301-307.

Thiagarajan, S. Semmel, D.S \& Semmel, M.I. (1974). Instructional Development for Training Teachers of Exceptional Children. Indiana: Indiana University.

Wahyuni, D., Masykur, R., \& Pratiwi, D.D.(2019). Pengembangan Multimedia Pembelajaran Matematika DeENGEMBANGAPendekatan Matematika Realistik. Jurnal Aksioma , 8(1), 32-40.
Yulianti, E., Zulkardi, \& Siroj, R. A. (2013). Pengembangan Alat Peraga Menggunakan Rangkaian Listrik Seri-Paralel Untuk Mengajarkan Logika Matematika Di Smk Negeri 2 Palembang. Jurnal Pendidikan Matematika, 4(1), 25-32.

Zulmaulida, R., \& Saputra, E. (2014). Pengembangan Bahan Ajar Program Linier Berbantuan Lindo Software. Infinity Journal, 3(2), 189-216. 